\title{
UTILIZATION OF AQUATIC WEED Salvinia molesta AS A RAW MATERIAL FOR BIOGAS PRODUCTION
}

\author{
Mujizat Kawaroe $^{1,4}$, Hefni Effendii, ${ }^{2,3}$, Zidni Ilma Palupi ${ }^{2}$, Neneng Sri Hendra ${ }^{3}$, \\ Dea Fauzia Lestari ${ }^{3^{*}}$ \\ ${ }^{1}$ Department of Marine Sciences and Technology, FPIK-IPB, Bogor \\ ${ }^{2}$ Department of Aquatic Resource Management of Environmental Research Center, FPIK-IPB, Bogor \\ ${ }^{3}$ Environmental Research Center, Bogor Agricultural University, Bogor, Indonesia \\ ${ }^{4}$ Surfactant and Bioenergy Research Center, Bogor Agricultural University, Bogor, Indonesia \\ ${ }^{\star}$ Corresponding email: deafauzialestari@gmail.com \\ Diterima: 18 Juni 2019/Disetujui: 19 Juli 2019
}

Cara sitasi: Kawaroe M, Effendi H, Palupi ZI, Hendra NS, Lestari DF. 2019. Utilization of aquatic weed (Salvinia molesta) as a raw material for biogas production. Jurnal Pengolahan Hasil Perikanan Indonesia. 22(2): 209-217.

\begin{abstract}
Salvinia molesta is an aquatic weed having very high growth rate. The high abundance of this species biomass could be utilized as a source of alternative energy. This research was aimed to utilize $S$. molesta as a substrate for biogas production using batch system in order to reduce euthrofication effect in a lake. Cow manure was used as starter for anaerobic process because containing bacteria. Proximate test was conducted to analyze the chemical characteristics of the aquatic weed. Chemical oxygen demand, total solid, and total volatile suspended solid of weed and manure were analyzed according to the APHA 2012 method. Biogas composition was analyzed with gas chromatography. The results showed that the S. molesta contained high lignin content and low C:N ratio. Hydrolisis and acidification process occured very rapid, resulting in an increase of the weed and manure mixture COD. In the other hand, the decreased of COD removal was caused by the massal death of methanogenesis bacteria. The total solid and total volatile suspended solid content were not significantly decreased. Potential biogas production from S. molesta was $58.16 \mathrm{~L}_{\mathrm{kg}} \mathrm{kg}^{-1}$ with $318.29 \mathrm{~mL}$.gram VS ${ }^{-1}$ day ${ }^{-1}$ of methane production. This production value was still low or compared to that of cow manure which have been established as biogass materials and need modification to improve the biogas production.
\end{abstract}

Keywords: anaerobic, batch method, biogas, Salvinia molesta

\section{Pemanfaatan Ganggang Air (Salvinia molesta) sebagai Bahan Baku Produksi Biogas}

\begin{abstract}
Abstrak
Salvinia molesta adalah tumbuhan air yang memiliki tingkat pertumbuhan sangat tinggi. Biomassanya yang berlimpah dapat dimanfaatkan sebahai bahan baku pembuatan energi alternatif. Penelitian ini bertujuan untuk memanfaatkan $S$. molesta sebagai bahan baku biogas dengan harapan dapat mengurangi eutrofikasi di danau. Kotoran sapi digunakan sebagai starter proses anaerobik karena mengandung banyak bakteri. Analisis proksimat dilakukan untuk menentukan karakteristik kimia bahan baku tumbuhan air tersebut. Analisis chemical oxygen demand, total solid, dan total volatile suspended solid dari tumbuhan air dan kotoran sapi dianalisis berdasarkan APHA 2012. Komposisi biogas dianalisis menggunakan gas kromatografi. Hasil menunjukan bahwa S. molesta mengandung lignin yang tinggi dan C:N rasio yang rendah. Proses hidrolisis dan asidifikasi yang terjadi dengan cepat menghasilkan peningkatan COD dari campuran kotoran sapi dan tumbuhan air. Di sisi lain, penurunan COD removal disebabkan oleh kematian masal bakteri metagenosis. Total solid dan total volatile suspended solid tidak signifikan menurun. Total produksi biogas dari S. molesta sebesar $58.16 \mathrm{~L} \mathrm{~kg}^{-1}$ dengan jumlah metana sebesar $318.29 \mathrm{~mL} . \mathrm{gram} \mathrm{VS}^{-1}$ day $^{-1}$. Nilai ini masih rendah jika dibandingkan dengan hasil biogas dari kotoran sapi yang sudah banyak dikembangkan dan masih butuh modifikasi metode untuk meningkatkan produksi biogasnya.
\end{abstract}

Kata kunci: anaerobik, biogas, metode batch, Salvinia molesta 


\section{INTRODUCTION}

Fossil fuels still dominate the primary energy consumption. Development of renewable energy becomes a priority due to the diminishing of fossil energy sources. One of the new renewable forms of energy that needs to be developed is biogas. Biogas is a product of anaerobic degradation of organic substrates. This process involves microorganism mixture and depends on various factors such as $\mathrm{pH}$, temperature, hydraulic retention time, and the C:N ratio (Yadvika et al. 2003). Indonesia has the potential for bioenergy development by utilizing biomass resources that are very abundant. Biomass used in the biogas production come from various sources, such as aquatic weed.

The use of aquatic plant biomass as an energy source gains a lot of attention (Nipaney and Panholzer 1987; Abbasi et al. 1990; Jain et al. 1992; Wilkie and Evans 2010; Raposo et al. 2011; Koyama et al. 2014). S. molesta is a floating aquatic weed belongs to ferns species. S. molesta is widely found in the slow current rivers, ponds, puddles, marshes and conduit. S. molesta has a rapid growth with a doubling time of 5-41 days and high density (Galam et al. 2015). S. molesta productivity is very high and can reach a dry weight of 57 ton per ha per year (Abbasi et al. 1990).

The use of $S$. molesta as the raw material of biogas was first investigated by Abbasi and Nipaney (1984), by adding $750 \mathrm{~kg}$ of fresh S. molesta to $5250 \mathrm{~L}$ of water in a biogas digester. The study showed that after 40 days of the retention time, the average biogas produced was $6.7 \mathrm{~L}$ per kilogram of wet weight and the concentration of methane was 4078\%. O'Sullivan et al. (2010) produced biogas using S. molesta substrate in a laboratoryscale digester (batch method) and generated $155 \mathrm{~L}$ of biogas per kilogram, with methane concentration as high as $65 \%$. Meanwhile, Mathew (2014) tested biogas formation using S. molesta substrate with batch system and produced $221 \mathrm{~L}$ of biogas per kilogram of wet weight.

The above studies suggest that $S$. molesta has the potential to be developed as a raw material for biogas production. In addition, the utilization of aquatic weed as biogas material can reduce the pollution from eutrophication in lake. This study was aimed to analyze the biodegradability of $S$. molesta for biogas production through anaerobic process using batch system and to analyze the biogas properties .

\section{MATERIALS AND METHODS Materials}

The fresh biomass of $S$. molesta was collected from the Situ Perikanan, IPB University, and was subsequently cleaned and dried. Proximate analysis based on the SNI method 01-2891-1992 was performed to determine the chemical characteristics of the weed (BSN 1992). S. molesta was used for Chemical Oxygen Demand (COD) analysis and the C:N ratio based on APHA (2012). Inoculum bacteria were obtained from dairy cow manure. Dairy cow manure was selected because it contains complete consortium of methane-producing bacteria (Methanomicrobium, Methanosarcina, Methanococcus, and Methanothrix) and more practical to use than other artificial inoculums (Haryati 2006). Dairy cow manure was obtained from Faculty of Veterinary, Bogor Agricultural University.

\section{Methods \\ Substrate preparation}

The biogas substrate was prepared from previously soaked $S$. molesta weed mixed with water with a ratio of 1:2. The mixture was then shredded in a blender to produce the substrate.

\section{Inoculum preparation}

The inoculum was obtained from a mix of dairy cow manure and water (1:1). Twenty four liters of the inoculum were added to the reactor (Figure 1) and were incubated for several days until the $\mathrm{pH}$ and the temperature were stable.

\section{Acclimatization}

Acclimatization was carried out to familiarize the degrading and methaneproducing bacteria with new environment. Acclimatization was carried out by providing organic materials for $0.5 \mathrm{~kg} \mathrm{COD} \cdot \mathrm{m}^{-3}$. day $^{-1}$, or equal to $1.041 \mathrm{~L}^{\mathrm{d} d a y^{-1}}$ (equation 1). Substrate 


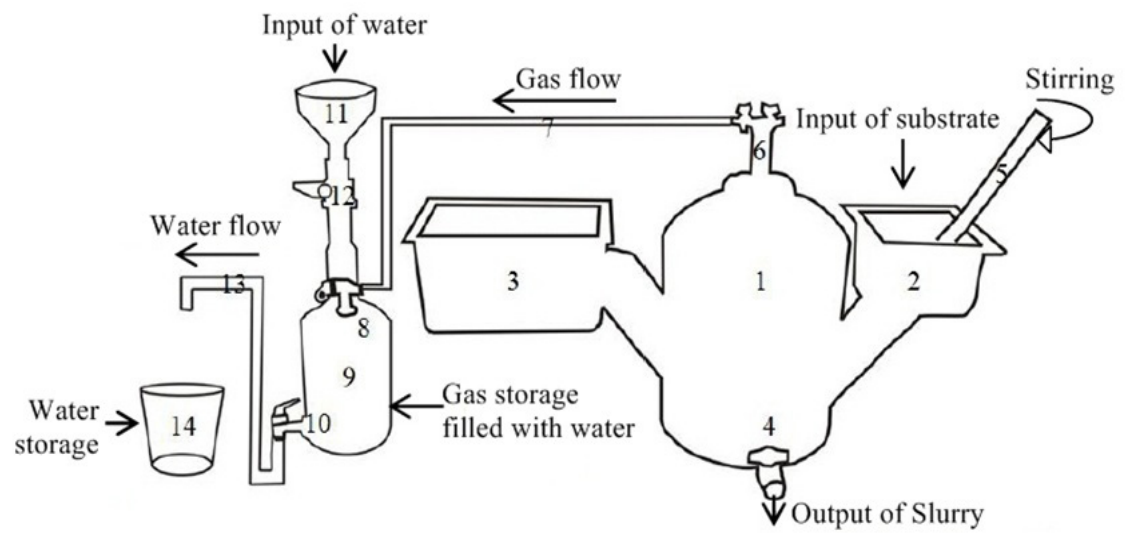

Figure 1 Design of the biogas reactor (Kawaroe et al. 2015). (1) Digester; (2) inflow of materials; (3) outflow of materials; (4) output crane of slurry; (5) stirrer; (6) gas channel; (7) hose of gas; (8) crane of gas entry and retrieval; (9) gas storage; (10) output crane of water; (11) funnel of water intake; (12) crane of water inlet; (13) water flow hose; (14) water body.

as much as $1.041 \mathrm{~L}$ was gradually added every two days to the bioreactor for 28 days. During the acclimatization process, the temperature, $\mathrm{pH}$, and volume of the biogas were measured.

$$
\mathrm{LPO}=\frac{\mathrm{COD} \text { in } \mathrm{x} \mathrm{F}}{\mathrm{V}}
$$

LPO = loading rate of COD $(\mathrm{kg}$ COD. $\mathrm{m}^{-3} \cdot \mathrm{day}^{-1}$ );

COD in $=\mathrm{COD}$ concentration of weed $\left(\mathrm{kg} / \mathrm{m}^{-3}\right)$;

$\mathrm{F} \quad=$ feed flow rate $(\mathrm{L} /$ day $)$;

$\mathrm{V} \quad=$ work volume of the reactor (L).

\section{Biogas production using batch method}

The biogas was produced using batch method. The production was done by removing the cow manure from the digester as much as half of the work volume. S. molesta substrate was then in equal volume as the slury. S. molesta substrate introduced in this stages was $7 \mathrm{~L}$. The production was carried out for 53 days, started on day 47 of 99 total research days. During the biogas production stage, the $\mathrm{pH}$, temperature, and volume were recorded every day. The Chemical Oxygen Demand (COD), Total Solid (TS), Total Volatile Suspended Solid (TVSS) were analyzed every seven days using APHA method (2012). The biogas composition was analyzed using gas chromatography. The COD data of the substrate and the slurry were used to calculate COD removal (CODr) using equation 2 and equation 3.

$$
\operatorname{CODr}(\%)=\frac{\text { COD in-COD out }}{\text { COD in }}
$$

$$
\begin{aligned}
\text { CODr }= & \text { COD removal percentage }(\%) ; \\
\text { COD in }= & \text { COD concentration in the } \\
& \text { substrate }\left(\mathrm{g} \cdot \mathrm{L}^{-1}\right) ; \\
\text { COD out }= & \text { COD concentration of outflow/ } \\
& \text { slurry }\left(\mathrm{g} \cdot \mathrm{L}^{-1}\right) .
\end{aligned}
$$

$$
\text { LCODr }=(\text { So-Se }) x \text { Fin }
$$

$\mathrm{LCODr}=$ volumetric COD removal (g/day);

So $=$ COD concentration in the substrate (g.L-1);

Se $=$ COD concentration of outflow $/$ slurry (g. $\left.\mathrm{L}^{-1}\right)$;

Fin $\quad=$ the flow rate of substrate (L per day).

The gas composition was expressed as percentage. These were are used to calculate the volume of methane produced.

$\mathrm{CH}_{4}(\mathrm{~L})=$ biogas Volume $(\mathrm{L}) \mathrm{x}$ methane $(\%)$

Biomass convertion into biogas was determined by calculating the amount of biogas produced (L) or cumulative volume divided by the number of observation day 
(equation 5). Moreover, the potential per unit of biomass conversion was detemined by dividing the biogas cumulative volume with biomass substrates used $(\mathrm{kg}$ ) (equation 6).

Production per biomass $\left(\mathrm{L} \cdot \mathrm{kg}^{-1}\right)=\frac{\mathrm{Vk}}{\mathrm{m}}$

$\mathrm{V}$ = cumulative volume of biogas (L),

$\mathrm{m} \quad=$ weight of plant material $(\mathrm{kg})$

Production per day $\left(\mathrm{L}^{\mathrm{day}}{ }^{-1}\right)=\frac{\mathrm{Vk}}{\mathrm{t}}$

$\mathrm{V}$ = cumulative volume of biogas (L),

$\mathrm{t}=$ time of batch cycle (day)

\section{RESULTS AND DISCUSSION Characteristics of the Chemical Constituents of S. molesta}

Chemical contents in S. molesta can affect anaerobic digestion process during biogas production. The characteristics of $S$. molesta contents was shown in Table 1.

The processing of S. molesta biomass into biogas was performed through anaerobic digestion. The anaerobic digestion is affected by environmental conditions such as $\mathrm{pH}$ and temperature, as well as chemical characteristics of the organic material. The analysis showed that $S$. molesta had a water content of $95.66 \%$ (Table 1). The result obtained was comparable with that of Mani (1998). Sufficient water content will help the biodegradation process. Lipid, carbohydrate, and protein are organic compounds that hydrolyzed by microorganisms (Chang et al. 2010). Those three organic compounds have a positive correlation with the amount of methane producted. The content of lipid, protein, and carbohydrate in S. molesta were relatively low (Table 1). Moozhiyil and Parauf (1986) found that the more mature the growth phase of $S$. molesta, the less protein content. Meanwhile carbohydrate content in S. molesta was $1.62 \%$. Generally, aquatic plants contain low carbohydrate content.

The lignin content of S. molesta in this study was $17.11 \%$ (Table 1 ). This value was not much different from the result obtained by Mani (1998), which was $15.94 \%$. Lignin is a complex organic compound and is resistant to degradation (Speece 1996). This property due to the basic structure of lignin, which forms a phenyl propane based complex threedimensional polymer compound (Kirk and Farrell 1987). The average of lignin content in S. molesta was 10.8 to $17.5 \%$ (Moozhiyil and Parauf 1986). Fifteen percents of lignin content is already enough to inhibit biodegradation (Pfeffer and Khan 1976).

The C:N ratio in S. molesta was 6.87 (Table 1). This value was below the minimum value of C:N ratio for optimal biogas production. Optimum C:N ratio for anaerobic digestion ranged from 20 to 30 (Mathew et al. 2014). A very high $\mathrm{C}: \mathrm{N}$ ratio indicates the excessive nitrogen consumption by methanogenic bacteria thus a little nitrogen can react with carbon. This will impact on the low production of the gas. On the other hand, if $\mathrm{C}: \mathrm{N}$ ratio is too low, it can lead to the accumulation of ammonia thus the $\mathrm{pH}$ will exceed 8.5 (Abbasi and Abbasi 2012).

Table 1 Characteristics of $S$. molesta chemical constituents

\begin{tabular}{lcc}
\hline \multicolumn{1}{c}{ Parameter } & Unit & Value \\
\hline Protein & $\%$ w.w & 0.08 \\
Lipid & $\%$ w.w & 0.2 \\
Moisture & $\% \mathrm{w} . w$ & 95.66 \\
Crude fiber & $\% \mathrm{w} . \mathrm{w}$ & 1.99 \\
Carbohydrate & $\% \mathrm{w} . \mathrm{w}$ & 1.62 \\
Lignin & $\% \mathrm{~d} . \mathrm{w}$ & 17.11 \\
ADF & $\% \mathrm{~d} . \mathrm{w}$ & 43.62 \\
C:N ratio & & 6.87 \\
COD of substrate & $\mathrm{mg} / \mathrm{L}$ & $11,518.99$ \\
\hline
\end{tabular}

Information: $\mathrm{w} \cdot \mathrm{w}=$ wet weight, $\mathrm{d} \cdot \mathrm{w}=$ dry weight 


\section{pH dan Temperature}

The performance of biogas installations can be controlled by studying variations in the parameters such as $\mathrm{pH}$ and temperature. $\mathrm{pH}$ is an important parameter that affects microbial growth during the process of anaerobic degradation. The $\mathrm{pH}$ value during the acclimatization process fluctuated but showed improvement, while the temperature condition tend to be stable in the range of 5.8 to 6.5 (Figure 2). The $\mathrm{pH}$ decreased at the early production, then increased and stable in the range of 6 to 7.7 (Figure 2). The stable $\mathrm{pH}$ value during the process of organic loading showed that the equilibrium was already achieved. The $\mathrm{pH}$ condition in the digester should be kept within the optimum range to produce biogas (6.8 to 7.2) (Yadvika et al. 2003). Temperature has a great influence in the production of biogas. The temperature during the acclimatization process ranged fluctuated between $25^{\circ} \mathrm{C}$ and $30^{\circ} \mathrm{C}$. The temperature during on biogas production process using batch method ranged from $27^{\circ} \mathrm{C}$ to $32^{\circ} \mathrm{C}$ (Figure 3). The temperature was in accordance with the results obtained by Mital (1996) where anaerobic bacteria activities are most active in the mesophilic temperature range $\left(20-45^{\circ} \mathrm{C}\right)$.

\section{Chemical Oxygen Demand, Total Solid, and Total Volatile Suspended Solid}

Anaerobic biodegradation conditions can be deserved from the change of COD, TS and TVSS. The COD value increased from 3248.42 $\mathrm{mg} / \mathrm{L}$ to $10335.45 \mathrm{mg} / \mathrm{L}$ in the last observation day. Chemical Oxygen Demand (COD) represents the total amount of oxygen required to oxidize organic materials chemically, into $\mathrm{CO}_{2}$ and $\mathrm{H}_{2} \mathrm{O}$. The COD continued to increase during the process of anaerobic degradation due to rapid hydrolysis and acidogenesis (Li et al. 2011). CODr percentage indicates the amount of organic material degraded during anaerobic degradation process. High CODr, indicates high biogas production (Kawaroe et al. 2015). A decrease in CODr every week indicates less-than optimal degradation of organic material in the digester. There was rapid decreasing of COD from day 50 to 57 , because of weed and cow manure degradation by anaerobic bacteria.

The Total Solid (TS) and Total Volatile Suspended Solid (TVSS) for 53 days of biogas production process was shown in Table 2. Overall, the value of TS and TVSS decreased, but increased on day 78 and 92. The CODr percentage for 8 weeks was shown in Table 2. The highest CODr was obtained in the first week (71.80\%). The decreasing of CODr value was in accordance with the length of production time, with the lowest value was observed in the last week (10.27\%). LCODr or volumetric removal of COD removal shows the removal COD value in the unit of volume. LCODr value was directly proportional to the COD removal.

The TS value decreased from the first day until the last day of observation. An increase occurred in the value of TS on day 78. This was presumably due to the addition of suspended

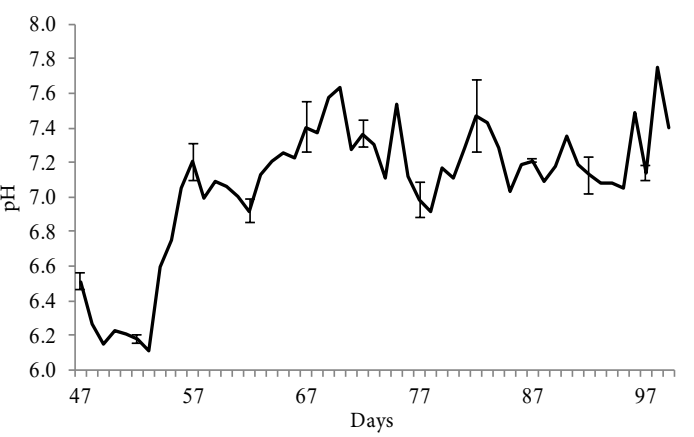

(b)

(a)

Figure $2 \mathrm{pH}$ during the process of (a) acclimatization, (b) biogas production. 


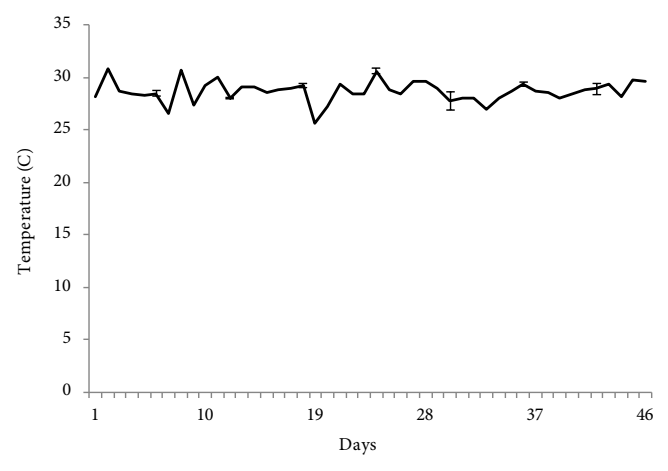

(a)

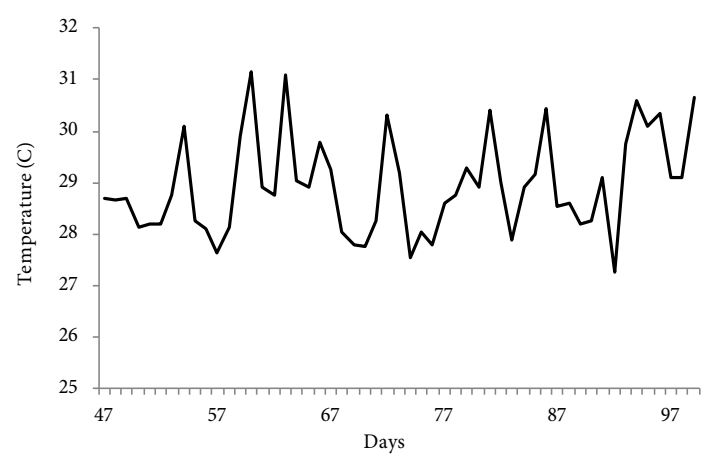

(b)

Figure 3 Temperature during the process of (a) acclimatization, (b) biogas production.

matter from bacterial biomass (USGS 2003). A decrease in TVSS during the process of anaerobic degradation was not significant.

\section{Gas Production}

Anaerobic degradation of organic material will produce gases, particularly $\mathrm{CH}_{4}$ and $\mathrm{CO}_{2}$. The production rate of biogas was observed and measured daily. Biogas production for 53 days was shown in Figure 4. The biogas production showed a fluctuative result with the highest production was observed at day 47 to day 55 and began to decline on day 57 .

The degradation process began on day 47 to day 99. The highest biogas production was achieved at day $53(5.05 \mathrm{~L})$ and the lowest production was on the day $90(1.59 \mathrm{~L})$. Biogas production during the process tend to decrease. Total production of biogas from anaerobic activity for 53 days of observation was $174.48 \mathrm{~L}$. Based on the cumulative volume, the rate of gas production in S. molesta was 3.29 L.day $^{-1}$. If it is seen from the amount of biomass used $(3 \mathrm{~kg})$, then the potential for the gas production that can be produced from 1 $\mathrm{kg} S$. molesta is $58.16 \mathrm{~L} . \mathrm{kg}^{-1}$.

Table 3 shows biogas production time percentage. Biogas contained several gases. The gas concentrations measured in this study was methane $\left(\mathrm{CH}_{4}\right)$ and carbon dioxide $\left(\mathrm{CO}_{2}\right)$, because both of the gases are the largest constituent of biogas. Besides these two gases, there are also byproduct gases such as hydrogen, nitrogen, oxygen, and ammonia with a small amount.

The process of anaerobic degradation produced biogas up to $174.48 \mathrm{~L}$. The value was higher than the result obtained by O'Sullivan et al. (2010), which was $155 \mathrm{~L}$ and Abbasi et al. (1992) which 137 L. Based on the cumulative biogas production, the potential for biomass production per kilogram of $S$. molesta was $58.16 \mathrm{~L}$. Abbasi and Nipaney (1991) examined the potential of biogas from Salvinia sp. and obtained biogas with a concentration range from 48 to $410{\mathrm{~L} . \mathrm{kg}^{-1}}^{-}$. The

Table 2 The value of TS, TVSS, COD removal and CODr volumetric

\begin{tabular}{cccccc}
\hline Day & TS $(\mathrm{mg} / \mathrm{L})$ & TVSS $(\mathrm{mg} / \mathrm{L})$ & COD $(\mathrm{mg} / \mathrm{L})$ & CODr $(\%)$ & LCODr $(\mathrm{mg} /$ day $)$ \\
\hline 50 & 18,425 & 5,738 & $13,995.00$ & - & - \\
57 & 11,962 & 4,925 & $3,248.42$ & 71.80 & $8,616.28$ \\
64 & 11,902 & 5,093 & $3,475.47$ & 69.83 & $8,379.74$ \\
71 & 7,983 & 6,560 & $4,435.13$ & 61.50 & $7,379.97$ \\
78 & 15,323 & 6,156 & $4,640.82$ & 59.71 & $7,165 / 67$ \\
85 & 14,419 & 4,611 & $6,591.77$ & 42.77 & $5,133.18$ \\
92 & 16,408 & 6,940 & $7,968.36$ & 30.82 & $3,699.05$ \\
99 & 10,321 & 5,518 & $10,335.45$ & 10.27 & $1,233.02$ \\
\hline
\end{tabular}




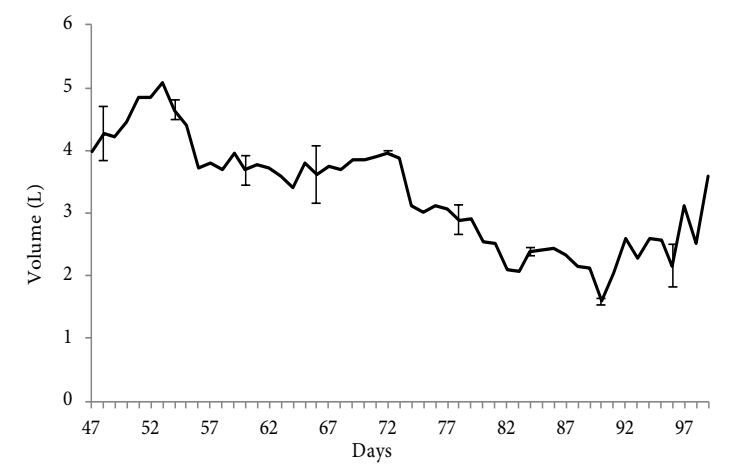

(a)

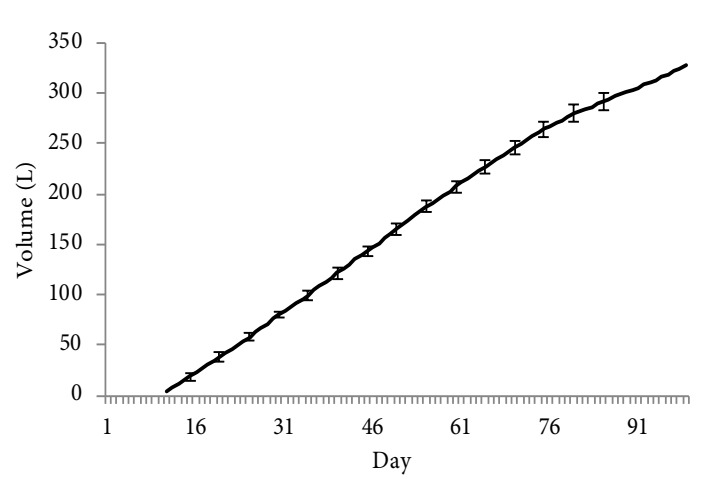

(b)

Figure 4 (a) daily biogas production; (b) cummulative biogas production.

volume of biogas generated in this study was also within that range.

The main component of biogas was methane $\left(\mathrm{CH}_{4}\right)$ and carbon dioxide $\left(\mathrm{CO}_{2}\right)$. The highest percentage of methane in this study was $54 \%$. Methane composition in biogas is $50-70 \%$ (Soerawidjaja 2009), and carbon dioxide was $30-40 \%$ (Rasi 2009). Methane concentration tend to decrease and biogas composition was dominated by carbon dioxide (Table 3). It can be related to the inhibition of methanogenesis by $\mathrm{CO}_{2}$ accumulation. Methane concentration increased again on day 99. Due to adaptation of degrading bacteria the structure and chemical compounds in $S$. molesta substrate. The percentage of methane produced is enough for combustible gas. The decreasing in viscosity of the slurry indicates anaerobic digestion is occuring

The acidogenesis and hydrolysis process run very rapid, it was suspected that there was formation of total ammonia nitrogen (TAN) and accumulation of volatile fatty acid (VFA). TAN and VFA are intermediate products that could inhibit anaerobic digestion process (Yen and Brune 2007). Formation of acid reduced the $\mathrm{pH}$ during acidogenesis stage in the beginning of biogas production process (Figure 4). Low $\mathrm{pH}$ condition was not conducive for the growth of methanogenic bacteria, resulting in the death of microorganisms. Undigasted microbial biomass as well as their particles and organic materials affected the TS and TVSS values (Table 2).

Total volatile suspended solid is an organic matter that can evaporate or can be converted into biogas. Production of $\mathrm{CH}_{4}$ and $\mathrm{CO}_{2}$ can be determined based on the content of TVSS (Table 4). Weekly volume of $\mathrm{CH}_{4}$ produced by TVSS value. $\mathrm{CH}_{4}$ production continued to decline, while $\mathrm{CO}_{2}$ tend to be stable. The amount of substrate that could potentially be converted into methane can be estimated through the level of volatile solid. S. molesta is

Table 3 Percentage of biogas production

\begin{tabular}{ccc}
\hline Day & $\mathrm{CH}_{4}(\%)$ & $\mathrm{CO}_{2}(\%)$ \\
\hline 50 & 77.39 & 22.61 \\
57 & 46.93 & 53.07 \\
64 & 51.95 & 48.05 \\
71 & 54.44 & 45.56 \\
78 & 54.04 & 45.96 \\
85 & 49.69 & 50.31 \\
92 & 22.98 & 77.02 \\
99 & 52.50 & 47.50 \\
\hline
\end{tabular}


Table 4 Production of $\mathrm{CH}_{4}$ dan $\mathrm{CO}_{2}$ based on TVSS

\begin{tabular}{cccccc}
\hline Day & $\begin{array}{c}\mathrm{TVSS} \\
(\mathrm{g} / \mathrm{L})\end{array}$ & $\begin{array}{c}\mathrm{CH}_{4}(\mathrm{~mL} / \mathrm{g} \\
\text { TVSS/7 days })\end{array}$ & $\begin{array}{c}\mathrm{CO}_{2}(\mathrm{~mL} / \mathrm{g} \\
\text { TVSS/7 days })\end{array}$ & $\begin{array}{c}\mathrm{CH}_{4}(\mathrm{~mL} / \mathrm{g} \\
\text { TVSS/day })\end{array}$ & $\begin{array}{c}\mathrm{CO}_{2}(\mathrm{~mL} / \mathrm{g} \\
\text { TVSS/day })\end{array}$ \\
\hline 50 & 5.74 & $3,879.61$ & $1,133.45$ & 554.23 & 161.92 \\
57 & 4.93 & $2,981.29$ & $3,371.65$ & $425 / 90$ & 481.66 \\
64 & 5.09 & $2,631.63$ & $2,434.19$ & 375.95 & 347.74 \\
71 & 6.56 & $2,195.30$ & $1,837.48$ & 313.61 & 262.50 \\
78 & 6.16 & $2,022.14$ & $1,719.74$ & 288.88 & 245.68 \\
85 & 4.61 & $1,822.65$ & $1,845.46$ & 260.38 & 263.64 \\
92 & 6.94 & 505.530 & 169.04 & 72.220 & 242.01 \\
99 & 5.52 & $1,785.82$ & $1,615.45$ & 255.12 & 230.78 \\
\hline
\end{tabular}

categorized as cellulose-based waste because it has a high lignin content. Hansen et al. (2004) used cellulose-based waste as a substrate for paper bags production. Average production of methane from cellulose-based waste was $379 \mathrm{~mL} \mathrm{CH4.gram.VS}{ }^{-1}$ during 50 days the production process. Average production of methane from S. molesta was $318.29 \mathrm{~mL}$ $\mathrm{CH}_{4}$.gram.VS ${ }^{-1}$ for 53 days of the production process. The results obtained in this study was comparable to that of Hansen et al. (2004).

\section{CONCLUSION}

The biomass of $S$. molesta could be used for biogas production. The total production for 53 days was $174.48 \mathrm{~L}$, with daily biogas production was 3.29 L. Potential production per kilogram of $S$. molesta was $58.16 \mathrm{~L}$ with methane concentration of $54 \%$ indicating that $S$. molesta potentially can be used as a substrate for biogas raw material. Based on the TS, TVSS, and COD conditions during the production process, batch system was not effective as a method to degrade S. molesta.

\section{REFERENCES}

Abbasi SA, Nipaney PC. 1984. Generation of biogas from Salvinia molesta (Mitchell) on a commercial biogas digester. Environmental Technology Letters. 5(12): 1-11.

Abbasi SA, Nipaney PC, Schaumberg GD. 1990. Bioenergy potential of eight common aquatic weeds. Biological Wastes. 34(4): 359-366.

Abbasi SA, Nipaney PC. 1991. Effect of temperature on biogas production from aquatic fern Salvinia. Indian Journal of Technology. 29: 306-309.

Abbasi SA, Nipaney PC, Ramasamy EV. 1992. Use of aquatic weed Salvinia (Salvinia molesta, Mitchell) as full partial feed in commercial biogas digesters. Indian Journal of Technology. 30: 451-457.

Abbasi SMT, Abbasi TSA. 2012. Anaerobic digestion for global warming control and energy-An overview. Renewable and Sustainable Energy Reviews. 16(5): 3228-3242.

[APHA] American public Health Assocoation. 1998. Standar Methods for the Examination of Water and Wastewater. $22^{\text {nd }}$ editions. Baltimore (USA): Victor Graphics Inc.

[BSN] Badan Strandarisasi Nasional. 1992. Cara Uji Makanan Dan MinumanSNI 01-2891-1992. Jakarta (ID): Badan Standarisasi Nasional.

Chang HN, Kim NJ, Kang J, Jeong CM. 2010. Biomass-derived volatile fatty acid platform for fuels and chemicals. Biotechnology and Bioprocessing Engineering. 15(1): 1-10.

Galam D, Silva J, Sanders D, Oard JH. 2015. Morphological and genetic survey of giant salvinia populations in Louisiana and Texas. Aquatic Botany. 127(20): 20-25.

Hansen TL, Schmidt JE, Angelidaki I, Marca E, Jansen JC, Mosbæk H, Christensen TH. 2004. Method for determination of methane potentials of solid organic 
waste. Waste Management. 24(4): 393-400.

Haryati T. 2006. Biogas: limbah peternakan yang menjadi sumber energi alternatif. Wartazoa. 16(3): 160-169.

Jain SK, Gujral GS, Jha NK, Vasudevan P. 1992. Production of biogas from Azolla pinnata $\mathrm{R}$. Br and Lemna minor L: effect of heavy metal contamination. Bioresource Technology. 41(3): 273-277.

Kawaroe M, Angustine D, Sumuddin A, Sofyan F. 2015. Anaerobic biodegradation using macroalgae Eucheuma cottonii to produce bio-methane. International Journal of Applied Engineering Research. 10(15): 35559-35565.

Kirk TK, Farrel RL. 1987. Enzymatic combustion The microbial degradation of lignin. Annual Review Microbiology. 41: 465-505.

Koyama M, Yamamoto S, Ishikawa K, Syuhei B, Toda T. 2014. Anaerobic digestion of submerged machrophytes: Chemical composition and anaerobic digestibility. Ecological Engineering. 69: 304-309.

Mani PK. 1998. Biochemical and biotechnological investigations on the water-fern Salvinia molesta Mitchell. [Thesis]. India (IN): Cochin University of Science and Technology.

Mathew A, Bhui I, Banerjee SN, Goswami R, Chakraboty AK, Shome A, Balachandran S, Chaudhury S. 2014. Biogas production from locally available aquatic weeds of Santiniketan through anaerobic digestion. Clean Technologies Environmental Policy. 17(6):1861-1688.

Mital KM. 1996. Biogas Systems: Principles and Applications. New Delhi (IN): New Age International Limited Publishers.

Moozhiyil M, Pallauf J. 1986. Chemical composition of the water-fern, Salvinia molesta, and its potential as feed source for ruminants. Economic Botany. 40(3): 375-383.

Nipaney PC, Panholzer MB. 1987. Influence of temperature on biogas production from Pistia stratiotes. Biological Wastes. 19(4):267-274.

O'Sullivan C, Rounsefell B, Grinham A, Clarke W, Udy J. 2010. Anaerobic digestion of harvested aquatic weeds: water hyacinth (Eichornia crassipes), cabomba (Cabomba caroliniana) and salvinia (Salvinia molesta). Ecological Engineering. 36(10):1459-1468.

Pfeffer JT, Khan KA. 1976. Microbial production of methane from municipal refuse. Biotechnology and Bioengineering. 18(9): 1179-1191.

RasiS.2009.Biogas composition and upgrading to biomethane. [Disertasi]. Finlandia (FI): University of JYVÄSKYLÄ.

Raposo F, RUbia MAD, Fernandez-Cegri V, Borja R. 2011. Anaerobic digestion of solid organic substrates in batch mode: An overview relating to methane yields and experimental procedures. Renewable and Sustainable Energy Reviews. 16(1): 863-877.

Speece RE. 1996. Anaerobic Biotechnology. Tennessee (US): Archae Press.

Soerawidjaja TH. 2009. Biogas, Teknologi Kemurgi TK 5038 Modul 13. Bandung (ID): Institut Teknologi Bandung.

[USGS] United States Geological Survey. 2003. A Summary Report of Sediment Processes in Chesapeake Bay and Watershed. Pennsylvania (US): U.S Geological Survey.

Wilkie AC, Evans JM. 2010. Aquatic plants: an opportunity feedstock in the age of bioenergy. Biofuels. 1(2): 311-321.

Yadvika, Santosh, Sreekrishnan TR, Kohli S, Rana Vineet. 2003. Enhancement of biogas production from solid substrates using different techniques: a review. Bioresource Technology. 95(1): 1-10.

Yen HW, Brune DE. 2007. Anaerobic codigestion of algal sludge and waste paper to produce methane. Bioresource Technology. 98(1):130-134. 